\title{
The galanin system in depression and antidepressant treatment: focus on the locus coeruleus
}

\author{
Simone B Sartori ${ }^{1 *}$, Anupam Sah ${ }^{1}$, Baosheng Zhao ${ }^{1}$, Inga Neumann², Rainer Landgraf ${ }^{3}$, Nicolas Singewald ${ }^{1}$ \\ From 18th Scientific Symposium of the Austrian Pharmacological Society (APHAR). Joint meeting with the \\ Croatian, Serbian and Slovenian Pharmacological Societies. \\ Graz, Austria. 20-21 September 2012
}

\section{Background}

Our knowledge about central changes underlying depressive disorders is still incomplete, but disturbances in monoaminergic neurotransmission are involved. There is also increasing evidence for a possible role of the neuropeptide galanin and its three G proteincoupled receptors in the pathophysiology and treatment of depression [1].

\section{Methods}

Using in situ hybridization we investigated whether transcriptional processes in the galanin system may be involved in the heightened depression-like behaviour of $\mathrm{HAB}$ rats selectively bred for high trait anxiety as compared with their low anxiety/depression (LAB) counterparts [2] and in the treatment responses to established antidepressant drugs. Subsequently, the modulation of depression-related behaviour by intra-cerebrally applied galaninergic ligands was studied in $\mathrm{HAB}$ and $\mathrm{LAB}$ rats.

\section{Results}

The abundance of galanin mRNA was increased in the paraventricular hypothalamus, the central amygdala and the locus coeruleus (LC), but not in the dorsal raphe of HAB as compared to LAB animals. Conversely, long-term (42 days, p.o.) treatment with either desipramine, paroxetine or tranylcypromine caused a general reduction in galanin mRNA expression in the locus coeruleus (LC) of unselected rats indicating a common response to antidepressant drug treatment while in the paraventricular

\footnotetext{
* Correspondence: simone.sartori@uibk.ac.at

'Department of Pharmacology and Toxicology, University of Innsbruck, 6020 Innsbruck, Austria

Full list of author information is available at the end of the article
}

hypothalamus galanin mRNA was increased by tranylcypromine only. This observed common effect of the antidepressants on galanin mRNA in the LC is in contrast to the finding in the $\mathrm{HAB}$ model raising the exciting possibility that altered coerulear galanin mRNA expression may be associated with depression-related behaviour. Indeed, intra-LC galanin caused a pronounced increase in the immobility of LAB rats indicating enhanced depressionlike behaviour while a galanin receptor antagonist reduced immobility in $\mathrm{HAB}$ rats.

\section{Conclusions}

The present data suggest that depression-like behaviours can be altered by interference with the galanin system and, thus, the galanin system may represent an interesting target for novel antidepressant pharmacotherapy. In particular, its modulation in the LC, where galanin highly coexists with noradrenaline, appears to be critical.

\section{Acknowledgements}

Supported by the Austrian Science Fund FWF and a Young Investigator Funding of the University of Innsbruck.

\author{
Author details \\ 'Department of Pharmacology and Toxicology, University of Innsbruck, 6020 \\ Innsbruck, Austria. '2Department of Zoology, University of Regensburg, 93040 \\ Regensburg, Germany. ${ }^{3}$ Max-Planck Institute of Psychiatry, 80804 Munich, \\ Germany. \\ Published: 17 September 2012

\section{References} \\ 1. Kuteeva E, Hökfelt T, Wardi T, Ogren SO: Galanin, galanin receptor \\ subtypes and depression-like behaviour. EXS 2010, 16:3071-3088. \\ 2. Landgraf $R$, Wigger A: High vs low anxiety-related behavior rats: an \\ animal model of extremes in trait anxiety. Behav Genet 2002, 32:301-314.
}

C Biomed Central

C 2012 Sartori et al; licensee BioMed Central Ltd. This is an Open Access article distributed under the terms of the Creative Commons Attribution License (http://creativecommons.org/licenses/by/2.0), which permits unrestricted use, distribution, and reproduction in any medium, provided the original work is properly cited. 
doi:10.1186/2050-6511-13-S1-A75

Cite this article as: Sartori et al:: The galanin system in depression and antidepressant treatment: focus on the locus coeruleus. BMC

Pharmacology and Toxicology 2012 13(Suppl 1):A75.

Submit your next manuscript to BioMed Central and take full advantage of:

- Convenient online submission

- Thorough peer review

- No space constraints or color figure charges

- Immediate publication on acceptance

- Inclusion in PubMed, CAS, Scopus and Google Scholar

- Research which is freely available for redistribution

Submit your manuscript at www.biomedcentral.com/submit 